\title{
FACTORS AFFECTING SOCIAL ECOMMERCE ADOPTION IN AN ARAB COUNTRY: FINDINGS FROM A QUALITATIVE STUDY
}

\author{
Kamel Rouibah, College of Business Administration, Kuwait University, krouibah@cba.edu.kw \\ Nabeel Al-Qirim, College of IT, United Arab Emirates University, Nalqirim@uaeu.ac.ae
}

\begin{abstract}
While Online Social Networks (OSNs) tools are being used on a large scale for socialization, their use for social ecommerce (s-commerce) is limited and unclear. This study aims to shed more light on this void by answer the following research question: What factors drive s-commerce adoption in Kuwait, and what products are sold over the Instagram accounts? This research uses a qualitative approach that involves interviewing 102 customers who are active users of s-commerce on Instagram. This study provides new insights on this important area alongside three directions: identifying 17 drivers of s-commerce adoption by customers in Kuwait; identifying important s-commerce measures/indicators and hence, extending our understanding about behavioral theory research (e.g. UTAUT 2, TPB); identified for the first time two new constructs in technology adoption namely the unique characteristics of Instagram and comparison of convenience. This study discusses these findings as well as their implication for research and practice.
\end{abstract}

Keywords: Social commerce, Instagram, drivers for adoption, qualitative data collection, electronic word of mouth, satisfaction, perceived value

\section{INTRODUCTION}

Online Social Networks (OSNs) are Internet tools that were made available online users all over the world. OSNs help those users meet and share common interest and thus, transforming the world into a small village. These tools include Facebook, WeChat, WhatsApp, Instagram, Twitter, Wikipedia, Tumblr, etc. Other tools like YouTube, DailyMotion, LinkedIn, etc., may serve other purposes as well such as education, professional networking, and helping learners, etc. However, despite the apparent widespread adoption of these OSN tools for socialization purpose (e.g. Chen et al., 2016), their use for social ecommerce (as s-commerce) is limited and not that clear (Hsiao et al., 2010; Stephen and Toubia 2010; Zhou et al., 2013; Huang and Benyoucef 2013; Hajli 2013; Hajli et al., 2015; Salvatori and Marcant 2015; Lee 2016; Akman and Mishra 2017). When compared to ecommerce research, the available literature on consumers' behavior that focuses on scommerce is not that mature (Akman and Mishra 2017). S-commerce is a new concept that was proposed by Yahoo in 2005and defined (Dennison et al. (2009) by IBM as "the concept of word of mouth applied to e-commerce. It is the marriage of a retailer's products and the interaction of shoppers with content" - in which sellers are connected in OSNs, and where sellers are individuals instead of firms (Stephen and Toubia 2010). Many niche service providers are embracing s-commerce in order to generate revenues and grow. Such social platforms allow individuals rent living spaces short-term lodging such as Airbnb, HomeAway, HouseTrip, Wimdu, and 9flats. Other platforms like Etsy which is a platform for the sale and purchase of handmade or vintage products, Fab, a platform that enables users to maintain an inspiration wall where they could upload and share design inspirations and introduced its "Live Feed", which enables users to share what they are buying, liking, and tweeting on Fab.com. Fancy is a platform where customers can discover and buy amazing things curated by the global community maintained by the web site. Blablacar is a platform for carpooling service, connecting drivers with empty seats to people travelling the same way. According to Global Digital Snapshot in 2016 (Chaffey 2016), the active OSNs users reaches 2.307 billion which represents $31 \%$ penetration rate, and this is increasing, and the s-commerce market, according to Statista (2016) is evaluated around 30 US billions, and $52 \%$ of marketers believe s-commerce is among the most important areas of investment (Greenlight, 2016). OSN tools are thus becoming popular platforms to expand ecommerce on a global basis through share, promote and sell products and services from business to customers as well as from consumers to consumers.

Among the five typologies of s-commerce as identified by Lee (2016): (i) social network platform sales; (ii) group buying and gifting; (iii) participatory commerce; (iv) person-to-person or peer-to-peer and business-toconsumer sales; and (iv) the sharing economy, this study will focus on the first category only. Unlike past 
studies that focused on social use of OSNs (Rouibah 2008; Magalhaes and Musallam 2014; Alwagait et al., 2015; Vishwanath 2015; Hu et al., 2015) this study focus on s-commerce for the following four reasons. First, scommerce is considered an emerging ecommerce trend that needs to be further explored and shed more light on the factors that lead to its adoption. This is to consider that a recent research revealed that $45 \%$ of respondents were not planning to make use of it, $26.4 \%$ never heard about it, and very few $(7.3 \%)$ have used it and plan to use it in the future (Statista 2016). Second, while the social use of OSN tools is increasing, there are limited research studies on s-ecommerce adoption in general and in the Arab world more specifically (e.g., Hajli et al., 2015). Third, we focused on Instagram because it is considered a popular communication tool that provides a list of functions which makes it a very attractive tool for s-commerce. It includes photo capturing and photo sharing tools which makes it a convenient online sell tool. Instagram has 400 million users world-wide and 80 million photos shared per day. It enables publishing multimedia files and the use of "likes". It also provides measures about the efficiency of the online selling process and feedback to both buyers and sellers. Finally, Kuwait is a GCC and an Arab country that belongs to the high uncertainty avoidance culture and therefore, represents a good context for our study since it is not covered by any previous research, and has the highest Instagram adoption rate according to the Arab Social Media Report 2015 (TNS 2015). In addition, Across the Gulf Cooperation Council (GCC) countries, Kuwait is among the highest in online shopping.

Accordingly, this study aims to answer the following two questions: What factors drive s-commerce adoption in Kuwait and what products are sold over the Instagram accounts?

\section{LITERATURE REVIEW}

The literature review shows that most studies were conducted on ecommerce than on s-commerce, and focused on developed countries (e.g. Rouibah, et al., 2016)

\section{S-commerce research}

S-commerce is a recent topic that started to receive increased attention from researchers. Liang and Turban (2011) were the first who published special Issue on s-commerce in the International Journal of electronic commerce. It was observed that few research studies focused on the issue from a customer's behavior perspective either in scientific journals (Hsiao et al., 2010; Stephen and Toubia 2010; Chen and Tao 2012; Zhou et al., 2013; Huang and Benyoucef 2013; Hajli 2013; Hajli et al., 2015; Salvatori and Marcant 2015; Lee 2016; Akman and Mishra 2017) or conferences (Chen and Tao 2012). We can classify these studies in four categories:

The first category includes studies that identified factors for s-commerce adoption (Hsiao et al., 2010; Chen and Tao 2012; Yoo et al., 2013, and Akman and Mishra 2017). Hsiao et al., (2010) studied the effect of trust of product information recommendations on social shopping networks website. Based on a sample of 1219 of Chinese customers, they found that perceived ability, perceived benevolence/integrity, perceived critical mass, and trust in a website were four important antecedents of trust in product recommendation in OSN sites. Trust in product recommendations was also found to increase customers' intention to purchase products. Chen and Tao (2012) focused on the effect of e-word of mouth in s-commerce. Based on an empirical study they explored the impact of users' participation on eWoM on s-commerce sites. They found that users' interpersonal and information-sharing do have significant positive impact on the amount and the dispersion rate of products' eWoM. Yoo et al. (2013) studied how eWoM affects online shopping (s-commerce) on their e-Loyalty. They developed a research model that includes several variables: Intrinsic motives, intrinsic motives, concern for others, self enhancement, social benefits, eWoM participation, personal site identification, and social site identification, and e-loyalty. They found several factors have direct and indirect effect on eloyalty including, eWoM participation, intrinsic and extrinsic motive, and personal site identification. Finally, Akman and Mishra (2017) investigated factors effecting s-commerce success in Turkey. They found that perceived trust, enjoyment, ease of use, social pressure, satisfaction and awareness all affect intention to use scommerce, which also mediates the effect of these factors on current use. They further suggested to conducting more studies based on qualitative data collection (e.g. interviews) that allows for deeper understanding of scommerce adoption problem.

A second category of studies conducted conceptual literature review. This is the case of Zhou et al., (2013) who gave an overview about s-commerce for research and practice. They also we proposed a research framework that integrates four key components (business, technology, people, and information) that helps us understand the 
development of s-commerce research and practice. They also report some finding related to academic and industry publications in s-commerce field that reveal recent trends and research topics.

Another literature review about s-commerce was conducted by Salvatori and Marcant (2015) that focused on understanding: What tools are used to support s-commerce? What companies do best perform in s-commerce? And what challenges are associated with s-commerce adoption? They reviewed 45 published papers related to scommerce. They found many tools were used is s-commerce including: recommendation systems, customer ratings, products reviews, transaction ratings, group buying, forum/blog/wiki discussion board, social wish-list, gift shipment, adding content tags, chat rooms, interaction with 3D models of items, and newsletter. The best companies that have applied successful s-commerce activities include: Amazon, eBay, Etsy, Kaboodle, WalMart, and Wists, Threadless. They also succeeded to identify eleven challenges facing s-commerce: development of feasible business models, development of new theories for s-commerce adoption, time and work to implement and manage s-commerce, some features in s-commerce web site may be initially challenging to use, making new IT platform more popular for s-commerce users, ensure security and privacy of users when adopting s-commerce, security issues related to no full control of external OSN tools, capturing correct user relationships, correct use of social networking, and environment configuring.

A third category developed and proposed research adoption models with no empirical data validation. For example, this is the case of Hajli H., (2013) who proposed a research model for s-commerce adoption that is based on the social support theory. This model predicts that forums and communities, customer ratings, customer reviews, customer referrals and their recommendations, and customer trust are facilitating to introduce new business plans for e-vendors. However, this model was not empirically tested.

A fourth category of studies proposed a new research model and a set of principles for guiding s-commerce design to increase sales and increase trust. Stephen and Toubia (2010) investigated whether allowing sellers to connect to one another in OSN increases sales, to understand the mechanisms through which the value of increasing sales is created, and how this value is distributed across sellers in the network, and how does the position of a seller in the network influence how much it benefits or suffers from the network. They found that allowing sellers to connect to OSN generates considerable increase in sales; the network's value lies primarily in making shops more accessible to customers who can browse the marketplace and enables them to creates a virtual shopping mall; and the sellers that benefit the most from the OSN are not necessarily those that are central to the network, but rather those whose accessibility is most enhanced by the network. Huang and Benyoucef (2013) applied the proposed model on two leading s-commerce platforms, Amazon and Starbucks on Facebook. They concluded that it is critical for s-commerce success is to achieve a minimum set of design features. These design features must cover individual, conversation, community and commerce levels. Lee (2016) identified three mechanisms that are central to the development of trust in s-commerce: communication and voluntary disclosure; barriers to entry and community policing. They described these mechanisms in four commercial settings: the sharing economy, the next generation e-commerce, the online escort services, and the online black markets in credit cards and controlled substances.

\section{A subset of Arab and none Arab ecommerce studies}

While s-commerce is considered a subset of ecommerce, some similarities do exist between the two fields, and this we include some of the e-commerce adoption studies that show factors affecting ecommerce adoption.

Ecommerce adoption studies in non-Arab countries focused on different issues. For example, some researchers conducted a literature review and investigated the motives for eWoM communication and proposed a classification model for motives of consumers (Hennig-Thurau et al., 2004). They found there are several motives that lead individuals to use eWoM: consumers' desire for social interaction, desire for economic incentives, concern for other consumers, and potential to enhance their own self-worth. Other investigated the moderating effects of trust propensity and gender on the impacts of perceived benefits and risks on user online behavior based on the benefit and risk paradigm (Chen et al., 2015). They found that trust propensity moderates the impact of perceived risk on customer satisfaction, perceived risk has effect on re-purchase intention, trust propensity and gender moderates impact of perceived benefit on intention to purchase while satisfaction has effect on purchasing intention. Chang and Wu (2014) examined the interaction among message, source, receiver characteristics, and receiver perceptions of information on negative e-WOM adoption based on combination of Yale model and attribution Theory in the context of socialization using OSN tools.

With regards to s-commerce research in the Arab world, most studies focused either on ecommerce issues including success of B2C, electronic payment, online travel and e-banking (Rouibah, et al., 2015; Rouibah et al., 
2016; Agag and El-Masry 2016; Tarhini et al., 2016) or socialization based on OSN (Rouibah 2008; Al-Omoush et al, 2012; Alwagait et al., 2015; Aladwani and Almarzouq 2016) with research on s-commerce is limited. These studies have identified a variety of factors that may impact ecommerce adoption such as: customer trust, familiarity, perceived enjoyment and presence of third party seal (Rouibah et al., 2016), perceived credibility and task-technology fit (Tarhini et al., 2016), perceived ease of use, perceived usefulness attitude, perceived behavioral control, and social norms (Rouibah et al., 2011), risk perception, system quality, information quality, service quality, perceived value and satisfaction (Rouibah et al., 2015) which will translate into more intentions to use and more repeated purchases.

Finally, to the best of our knowledge, only one study focused on s-commerce in the Arab world (Al-Debei et al., 2015). Authors developed a research model based on the Theory of Planned Behavior (TPB) for e-shopping in Jordan that integrates eWoM. They found several factors including perceived benefits/ perceived value, customer trust, perceived web quality and eWoM effect directly and indirectly attitude toward online shopping.

\section{Instagram use in Kuwait}

Instagram was founded in 2010. It is an OSN and a mobile photo/video sharing tool service. This unique online mobile networking service did not only enable individuals to share their photos but it quickly grew to a large online shopping media. In fact, big companies understood the strategic need to create their own Instagram accounts to reach to a maximum number of audience and to easily connect with their current customers as well as to attract new ones.

Instagram enables entrepreneurs/startups to know how popular his business is by counting the number of people following him and the number of likes he gets on a photo related to a product. There is also a "comment" section where users/customers provide their comments about a post and mention other users. These comments are helpful for entrepreneurs/startups. Comments are also helpful for customers because they show whether the products or services are as good as the entrepreneurs/startups claim creating a discussion thread round a topic.

According to Kuwaitiful (2017), Kuwait is considered the most popular country-hashtag on Instagram with around 8.2 million photos. Instagram is being adopted as an entrepreneurial platform for handmade accessories, handcraft and family products (Theatlantic.com 2013; Kuwaittimes.net 2016).

Instagram includes many initiatives created by local Kuwaiti bloggers, such as @ascia_akf that has 1.2million followers,@dalalid (1 million followers) (see Błąd! Nie można odnaleźć źródła odwołania. for list of additional entrepreneurs/ startups in Kuwait and their performance). These entrepreneurs/startups are mainly interested in food, makeup, and fashion. They gained so much popularity in Kuwait that they started making advertisements for others and even big companies and are constantly attending special events either in Kuwait or other GCC countries. Then they post photos on their Instagram accounts about these events weather it is the opening of a new restaurant, store, or about a new collection of goods that just arrived. This attracts more customers to Instagram, boosts fashion selling and trends, and raises s-commerce adoption in Kuwait.

People quickly took advantage of Instagram by using it to advertise for their businesses. Users need only to install the app on their mobile devices, create accounts, and post photos of products and services they provide. Another advantage of Instagram is that it promotes establishing new startups. Unlike B2C web sites that are somehow not easy to navigate and use, Instagram is easy and simple to use even among those who have low level of IT literacy.

\section{RESEARCH METHODOLOGY}

This study is part of large project that aims to build and validates a research model for s-commerce in an Arab country. In order to achieve this objective, this research follows earlier calls for implementing plural information systems research methods (Gallivan, 1997) and ecommerce (Poon and Swatman, 1999) so that what one research method omits can be supplemented by the other (Orlikowski and Baroudi, 1991). In addition, this research follows a rigorous research methodology that was proposed by Hong et al. (2014) to implement and justifies the choice of selected constructs as the contrast of previous studies.

This study adopts "mixed research method" (Hong et al., 2014) that combines both qualitative and quantitative data collection to shed more light on motives that drive s-commerce adoption based on Instagram in Kuwait. For the purpose of this study, the first phase of this project involves qualitative data collection based on interviewing a sample of s-commerce customers in Kuwait. 


\section{Sample and procedure of data collection}

The population consists of all adults in Kuwait, including men and women since the number of Instagram users is among the highest one in the world. This study targets students from a leading business schools as potential respondents to conduct interviews and highlights motives to use s-commerce. This study selected a sample of students who were enrolled in an introductory course about e-commerce and s-commerce. Twenty one students were prepared to conduct interviews with a sample of active users of Instagram.

The selected students were asked to interview five of their network on Instagram composed of family members, friends, and colleagues who are active users on Instagram and have already purchased from s-commerce accounts. Based on the interviews we then identified motives that encourage Kuwaitis to shop over Instagram for s-commerce. Information collected during the interviews included: (i) demographic information about the Interviewee (gender and age); (ii) position of the interviewee (student, employee, retired, or job seeker, or not working); (iii) start and end time of interview, and last (iv) the main drivers for e-shopping over Instagram using free format as quoted by the interviewees; (v) and finally identify two most important Instagram account addresses for s-commerce according to the interviewee's knowledge in Kuwait as well as to describe their products sold over these accounts. A total of 102 interviews were conducted (65 interviews in the spring 2016 and 37 during the fall 2017). Interviews were in Arabic and English languages, recorded and then transcribed later for our analysis.

\section{Demographic data}

Demographic data relating to interviewees are presented in Table 1

Table 1. Demographic data related to interviewees

\begin{tabular}{|l|l|}
\hline variables & Measures \\
\hline Gender & Male: 19 \\
& Female: 83 \\
\hline Age & Minimum: 13 years \\
& Maximum: 45 years \\
\hline Position & Average: 24.15 years \\
& Student: 60 \\
& Employee: 20 \\
& Not working: 4 \\
\hline Interview & Students and Instagram owners of s-commerce: 4 \\
& Employee and Instagram of s-commerce: 4 \\
\hline & Minimum time: 05 minutes \\
& Maxim time: 10 Minutes \\
& Average: 8 minutes \\
\hline
\end{tabular}

\section{RESULTS}

\section{What are the main drivers for using s-commerce in Kuwait?}

The analysis of the interviews revealed the existence of 17 motives toward s-commerce adoption in Kuwait by the 102 participants. Although the analysis of the qualitative data revealed some factors which are similar to previously identified categories, it also identifies new motives and gave more details about those identified factors. The research findings and factors are grouped and categorized according to themes taking into consideration the technological innovations theories and models. This is described in the following sections.

1-Perceived value and perceived relative advantages: As expected by different theory behavioral models such as UTAUT and its variations (UTAUT1: Venkates et al., 2013; UTAUT2: Venkatesh et al., 2012), and information success model in ecommerce (Rouibah et al, 2015), perceived value (also known as perceived usefulness in TAM and performance expectation in UTAUT 2, and relative advantage in innovation diffusion theory) was extensively mentioned by interviewees ( $n=43$, see Table 2$)$ as one of the main driver toward using s-commerce. This construct is broader than perceived usefulness (performance expectancy in UTAUT2), which refers to the extent to which a person believes that using a system will improve his/her job performance. Perceived value results from an evaluation of the relative rewards and sacrifices associated with the offering (in 
our case s-commerce based on Instagram accounts). Customers are inclined to feel equitably treated if they perceive that the ratio of their outcome to inputs is comparable to the ratio of outcome to inputs experienced by the company (Oliver and DeSarbo 1988). While perceived value has received extensive research in ecommerce, it is unclear how customers perceive its meaning in s-commerce and how current s-commerce adoption studies may apply in theory based studies. The following are items of perceived value cited by interviewees: Instagram allows me to: "adapt, follow and catch up with fashion and trends in Kuwait"; find the latest trends/fashion up to date", "buy products from many available options"; "see product descriptions through available pictures"; "buy cheaper products than face to face stores"; "find and purchase unique products that that fulfill my needs and satisfy my taste"; "offer differentiated products than face to face stores"; "allow to pay using cash on delivery (CoD) instead of credits cards"; "offer possibility to negotiate prices before shopping with the seller"; "save search time using a single page and easier compare to B2C web sites"; "save time instead of going to malls/stores because I have no time to go to the mall and shop for my children", "allow to shop from home and get product delivered"; "shop from one location / a single page that includes many pictures"; "easily check and compare prices with just a few clicks"; "give freedom to determine which online account offers the most affordable item customer will buy"; "convenient to order since it can be taken form your home". In addition, other participants perceive Instagram as a platform that: "promotes various goods at suitable competitive prices"; "exploit the power of pictures in order to attract customers to buy" and allows "youth entrepreneurs to initiate their business from home without having to invest high investments since the business is done from home and reach all people connected to internet".

Table 2. Summary of drivers toward s-commerce adoption via Instagram in Kuwait

\begin{tabular}{|c|l|c|c|l|l|}
\hline Nbr & Construct & Frequencies & Nbr & & Frequencies \\
\hline 1 & Perceived value & 43 & 9 & Satisfaction & 8 \\
\hline 2 & Perceived ease of use & 24 & 10 & $\begin{array}{l}\text { Comparison of } \\
\text { convenience }\end{array}$ & 7 \\
\hline 3 & Propensity to trust and customer trust & 20 & 11 & $\begin{array}{l}\text { Perceived } \\
\text { enjoyment }\end{array}$ & 7 \\
\hline 4 & Service quality & 17 & 12 & Social presence & 6 \\
\hline 5 & Unique characteristics of Instagram & 16 & 13 & Perceived risk & 5 \\
\hline 6 & Attitude & 15 & 14 & Culture effect & 4 \\
\hline 7 & eWoM & 10 & 15 & $\begin{array}{l}\text { Perceived critical } \\
\text { mass }\end{array}$ & 4 \\
\hline 8 & Trust of Instagram / internet & 9 & 16 & $\begin{array}{l}\text { Privacy in } \\
\text { shopping }\end{array}$ & 4 \\
\cline { 3 - 5 } & & & 17 & Habit & 3 \\
\hline
\end{tabular}

2-Perceived ease of use (PEOU): As expected from behavioral theory models (UTAUT and its variations) PEOU, also known as effort expectancy in UTAUT2, was cited as the second most frequent driver toward scommerce adoption ( $\mathrm{n}=24$, Table 2). PEOU refers to the extent to which a person believes that using the system will be free of efforts. While this construct has received extensive research in previous e-commerce studies, it is unclear how customers perceive its meaning in s-commerce. Quotations of respondents included the following: "I can contact the buyer easily and directly with my mobile phone"; "It is easy to compare prices before shopping"; "I can choose the products I want, send them my order by phone or by e-mail"; "It easier to shop than buying from B2C web sites"; "It allows fast shopping than B2C web sites"; "I can purchase and place orders while I continue to socialize through Instagram"; "It is very easy to access one single page, and navigate through pictures to select and purchase the products I want to buy"; "It is easy and simple to shop over Instagram compare to the complexity of using B2C web sites specially for low literacy and old people"; and "It is easy to purchase from a single page because I don't know how to buy from B2C websites".

3-Propensity to trust / customer trust: This construct is becoming the main important factor that drive people to go online and purchase. Because of risks, people need to develop trust in order to lessen these perceptions. Customer trust refers the consumers' belief that the online transactions will be processed in accordance with their expectations (Rouibah et al., 2016). Very few papers have investigated customer trust in s-commerce (Hsiao et al., 2010; Akman and Mishra 2017). This construct has been cited as the third most important factor by interviewees $(\mathrm{n}=20$, Table 2). Here are some of their quotations: "I do trust and prefer to buy from face to face stores"; "I don't buy from Instagram because I don't trust the sellers"; "I don't shop on Instagram because I have faced a problem with a seller before"; "I neither trust internet nor trust Instagram accounts for 
s-commerce"; "I trust Instagram as a communication channel to sell and buy products"; "I don't purchase clothes from Instagram. I only buy flowers from a trusted Instagram account"; "I don't trust all sellers... there are accounts that sell cheated products"; "I don't trust all accounts. There are accounts that sell products as branded but they are fake and copied products".

4-Service quality: It refers to the quality of the overall support delivered to customers by the seller (Rouibah et al., 2015). It is an important construct in the information system success model of Delone and McLean. The scommerce context literature is silent to what this construct means. Service quality was identified in this study as the fourth most cited factor $(\mathrm{n}=17$, Table 2). Here are some quotations of participants. Instagram "allows to return products if a customer is not satisfied"; "offers easiness for customer to reach the seller to get more information through different communication tools (phone calls, e-mail whatsApp, Instagram, etc.) and getting information about product before purchase"; "offers possibility to replace or exchange purchased products if a customer is dissatisfied. However it is very hard to exchange it if it is ordered from B2C web sites outside Kuwait"; "allows free of delivery at home"; "allows faster and home delivery than does B2C web sites"; "offers demonstrations/sampling of products at home of purchaser before shopping"; "I can get the products while I am sitting at home and most of the time the delivery is on the same day and free"; "I prefer to buy from Instagram because there is no delivery costs as the case of B2C websites are high if I purchase from outside Kuwait"; "I can negotiate prices of products sold over Instagram while this is not the case of B2C web sites that apply fixed prices,"; "It is easy to communicate with the seller to get enough information about goods before shopping"; "I can return purchased products If I am dissatisfied. However, this is not the case when I buy from B2C web sites, outside Kuwait, because of high shipping cost".

5-Unique characteristics of Instagram: This is a new construct in information system adoption literature and none past study has investigated it before. We define it as the unique features that characterize Instagram as platform for s-commerce and make it attractive and distinct from B2C web sites. This construct was ranked as the fifth most cited driver toward s-commerce adoption $(\mathrm{n}=16$, Table 2). Here are the quotations of some participants. Instagram "offers possibilities for customers to ask about prices and negotiate them before shopping"; "is very easy to access on one single page, and navigate through pictures to select the products I want to buy"; "has unique characteristic such as posting pictures and videos, which display products for customers"; "Unlike twitter, more information about the product can be posted without obligation to a certain number of characters, as well as to display and incudes customers' opinions"; "s-commerce accounts dos not need payment with credit cards as the case of $B 2 C$ websites, because they use payment cash on delivery $(C o D)$ "; "unlike B2C web sites products and goods are displayed in a single page in Instagram accounts".

6- Attitude: It is an important construct in behavioral theory models (TRA, TPB, TAM and its variation). It refers to an individual's positive or negative feeling (evaluative effect) about performing the target behavior (adoption of s-commerce). Despite that UTAU2 did not include attitude, and in line with previous studies on ecommerce adoption, attitude was found to be an important diver ( $\mathrm{n}=15$, Table 2). Here are the quotations of participants, which are in line with measures of prior research on the consumer behavior. "I don't like to buy from Instagram"; "I like to use Instagram for socialization but I don't love to use it for s-commerce"; "I hate scommerce because products shown on pictures do not match all the times the real products customers receive"; "I love shopping from Instagram" and "I prefer to buy from Instagram instead of B2C web sites"

7-eWoM: It refers to any positive or negative statement made by potential, actual, or former customers about a product or company, which is made available to a multitude of people and institutions (Hennig-Thurau et al., 2004). Very few studies have studied the role played by eWoM in s-commerce (Yoo et al., 2013 Al-Debei et al., 2015). However, many other studies have ascertained the effect of eWoM in ecommerce and social use of OSN (Yoo e al., 2013; Chen et al., 2015; Agag and El-Masry 2016; Weitzl 2016). Results of our interviews revealed the importance of eWoM in adopting s-commerce $(n=10$, Table 2). Instagram is becoming a powerful tool for scommerce in Kuwait because it enables to spread eWoM through many ways. These are some quotations of respondents about the effect of eWoM on their adoption of s-commerce. "It offers ability to share views on items customers want to purchase with their family or friends and get their feedback instantaneously". "It allows customers to viewing opinions of other in a clear, easy and very influential manner for purchasing". "It enables to view and read other customers' recommendations (either positive or negative) that can encourage or deter me from purchasing". "I read comments of other customers before shopping in order to take the right decision". "I can see and read people's opinions and comments about products before shopping". "I can see the product description under the pictures of the product, as well as opinions of previous customers". "Reading customer opinions influence my decision to engage in a purchasing". "I read customer generated content to identify which attractive products I need to buy". "It gives me more details about products I want to buy either 
through pictures or customers reviews; so it makes my buying easier and rational". "Customers can put comments and questions about the products that they like and share them with their family members and friends". "Hashtags helps to spread the Instagram accounts through e-WoM in Kuwait". "Instagram has the power functions and ability to share views on items you want to purchase with family or friends and get their feedback instantaneously".

8- Trust of internet / Instagram: Trust is a complex construct that has many facets as shown by prior studies (Rouibah et al., 2016). It includes propensity to trust/customer trust as well as trust of internet as a communication channel for selling online. Many respondents have expressed their trust perceptions of Instagram and internet when they conduct online transactions $(\mathrm{n}=9$, Table 2$)$ such as the following: "I am in favor of using Instagram to shopping because I do trust Instagram"; "Internet is safe and I do have confidence in e-commerce accounts that sell over internet". This corroborate with the findings of previous studies in ecommerce adoption, such as Schaupp et al., (2010) about the role played by trust of internet on intention to use e-payment.

9- Satisfaction and dis-satisfaction: Satisfaction refers to the summary psychological state resulting when the emotion surrounding disconfirmed expectations is coupled with the customer's prior feelings about the consumption experience (Oliver 1981). Thus, it results from the difference between expectation and real experience. When the former is less than the later, then it turns to be a satisfaction, and it is dissatisfaction if the latter is less than the former. Following results of past studies on application of the information success model of Delone and Mclean, satisfaction was quoted by interviewees as another driver that influences customers' intention to adopt s-commerce $(\mathrm{n}=8$, Table 2). Here are some of their quotations: "S-commerce provides me with free delivery service so the products arrived to my home in a short time. So I am very satisfied"; "If there is a defect in the goods I purchased through s-commerce I can exchange it instantaneously or in short time, which makes me fully satisfied"; "I have ordered many products from Instagram. I found that it saves a lot my time, efforts and provides me with full satisfaction".

While some interviewees stated their full satisfaction, others, have quoted they were dissatisfied such as the following: "I don't like to buy from Instagram as sometimes prices are the same as in face to face stores"; "I don't buy from Instagram because I don't trust the sellers. I experienced once and I was completely dissatisfied because of the mismatch between the pictures of products on Instagram and the real product I received"; "I have faced once a problem with a seller before. I don't want to have the same bad experience"; and "I have ordered once a dress from Instagram. It was my first and last time, the dress was totally different from the picture I saw on the Instagram account".

10- Comparison of convenience / Attractiveness of Instagram: Comparison of convenience is a new proposed construct that is identified for the first time by this research. We define is as the attitude consumers hold when they are comparing functions of Instagram to conduct s-commerce with traditional B2C web sites and state their preference vis-à-vis of one of the two alternatives. It was cited at the tenth important driving factor toward s-commerce adoption $(\mathrm{n}=7$, Table 2$)$ in all interviews in in which respondent agreed that shopping through Instagram is more convenient than conducting it over B2C web sites. These are some of the respondents' quotations. "Instagram is more convenient than face to face stores with fixed working hours"; "Purchasing from Instagram accounts is more flexible than B2C web sites"; "Purchasing from Instagram accounts is more convenient because I can contact the buyers easily and directly with mobile phone before shopping"; "Instagram save my time and energy and enables me to shop from one location that includes many pictures instead of B2C web sites"; "Products sold over Instagram have less time delivery compare to B2C web sites; "It is possible to exchange the product when I buy it from Instagram, however it is very hard to exchange it if I order it from B2C web sites outside Kuwait"; "The price of products sold over B2C web sites are fixed and cannot be exchanged, prices of products on Instagram can be negotiated". "I prefer to shop through Instagram that include only one page instead of B2C websites". "I find it easier to shop through Instagram than B2C websites". "I feel secure when I purchase from Instagram accounts than B2C websites because I pay cash on delivery".

11-Perceived enjoyment: Derived from the theory of flow, perceived enjoyment is an intrinsic psychological motivation. It refers to the extent to which using a technology procures happiness and enjoyments for endusers/customers. This construct has received extensive focus on e-commerce adoption (e.g. Rouibah et al., 2016) but was approached by s-commerce studies. In line with previous findings in ecommerce many interviewees quoted they adopted s-commerce because of the enjoyment they perceived while using Instagram. Expository 
exemplars include: "shopping through Instagram accounts is fun while browsing picture", and "I find enjoyable to socialize a well as to shop via Instagram".

12-Social presence and preference for face to face stores: Social presence is grounded in social presence theory that elaborates the ability of a communication medium to transmit social cues (Lu et al., 2016). It refers to the salience of the other in a mediated communication and the consequent salience of their interpersonal interactions (Lu et al., 2016). While this construct is recognized to be an important factor, very few studies have shown its importance in s-commerce (Lu et al., 2016). In line with the finding of Lu et al., (2016) this study has found that social presence is also a factor that deters customers to adopt s-commerce in Kuwait. These are quotation of two interviewed participants. "I like to shop from face to face instead of Instagram accounts because I like to see products in real life"; "I like shopping in face-to-face stores where I can touch and feel the products. Buying from internet involve part of perceived risk", "I don't prefer to buy from Instagram accounts because I don't feel sense of sociability as compare to shopping from face to face stores".

13-Percived risk: There is an extensive body of studies that have shown the negative perceived risk on consumer adoption of ecommerce (Rouibah et al., 2015; Rouibah et al., 2016). Result of our interviews corroborate with the findings of these studies. Here are examples of participants' quotations: "Instagram has less risk compare to B2C web sites that need use of credit cards and increase risk of fraud and decrease trust"; "Product sold over Instagram may be fake, copied, and not from branded companies as they may claim"; "most of the products sold over Instagram accounts are imported from outside Kuwait and could be found on a trusted international website"; "I do prefer to buy from trusted web site to avoid risk of fake/copied products"; "I pay products purchased over Instagram via CoD which I feel is more secure and decrease my risk perceptions"; "The use of CoD in association with Instagram presents less risk for me compare to B2C web sites that need use of credit cards and increase risk of fraud"; "There is no mandatory use of e-payment when purchasing over Instagram. The use of CoD offers me more safety than buying from online web site with credits card".

14-Culture effect of s-commerce adoption: Many studies have ascertained that the adoption of information system is affected by culture (Rouibah et al., 2009). Besides the previous drivers toward s-commerce adoption, participants in interviews have also added possibility to negotiate price before shopping, "I can negotiate prices of products on Instagram before shopping", "I can bargain prices before shopping, this I why I trust more accounts over Instagram as a purchasing channel"; as well as non-rational reason such as "I buy from Instagram accounts in Kuwait in order to support national and local products, since these products are the initiatives of local entrepreneurs and youth".

15- Perceived critical mass of users: Perceived critical mass refers to the perception of an individual that many members of a community group have adopted the technology (reputation) and therefore perceived critical mass generates peer pressure among group members to adopt the same behavior, here s-commerce (Rouibah 2016). Following the finding of previous studies, our interviews also reveal the important role of this construct in driving adoption. Here are example of interviewees' quotations: "I use Instagram because it is the most social media prevalent in Kuwait and many individuals use it"; "There are many ecommerce accounts in Kuwait over Instagram because such activities do not need a business license"; "Instagram is very popular in Kuwait and all my friends and family members use it"; "The huge number of people who use Instagram for s-commerce encourage me to buy from it".

16- Privacy during shopping: Privacy refers to a state in which one is not observed or disturbed by other people. It is the state of being free from public attention. While this construct has been investigated in IS adoption in a lot in western studies, surprising to not very few studies in the Arab region have investigated its effect on technology adoption (Rouibah and Hasan 2006). Our participants have expressed and quoted the importance of using Instagram because it guarantees their privacy during online shopping. These are some of their stated quotations: "Compare to face to face stores, Instagram grantees and ensures some of my privacy during the purchase process"; "Shopping over Instagram gives you privacy because you won't have people looking at you while you shop. Not only that, but the receipts are usually made so that no one will know what you bought"; "Shopping over Instagram allows customers to keep their shopping privacy. There are some products that you don't want to buy publicly (e.g. women internal clothes). With s-commerce you can buy any products while maintaining your privacy".

17- Habit: It refers the extent to which people tend to perform behaviors automatically (Limayem et al., 2007). As expected by the UTAUT 2 (Venkatesh et al., 2012), habit was also cited by interviewees as a driving factor toward s-commerce adoption in Kuwait. These are some of the quotations given by our interviewees "I found 
that shopping through Instagram is much more convenient than shopping through $B 2 C$ websites because I am a frequently user of Instagram more than any other websites. It is the only online social network I use"; "I shop through Instagram because I got used to it and I don't think why I am using it".

\section{What products are sold over the Instagram accounts in Kuwait?}

There are many Instagram accounts for s-commerce in Kuwait, which are increasing. These accounts sell a variety of products such as: selling accessories (bracelets, necklaces, wallets, belts, watches, sunglasses, jewelry, baby care, pharmacy products, bags, body supplements, electronics, flowers, office supplies, phone accessories, new and used products, sports equipment, and body supplements), services (birthday parties organizers, clinical services, trips offers, travel, designing and modeling clothes), home-made foods (universal dishes, cakes, chocolates, chips, nuts, healthy sandwiches, pasta, pastries, salads, and sweets), home-made clothes (women and men clothes, babe clothes, and collections for brides), home-made accessories (gift boxes, handbags, handmade vintage girly dresses for kids, tools for kitchens, and kids shoes), beauty products (skin care products, skin cream, body and hair care products, beauty cosmetics, hair creams, oils, makeup and beauty products, perfumes, etc.). In addition, for the identified accounts the minimum number of following these accounts is 1 while the maximum number is 7772 , with an average number of 988 . The minimum number of individuals who follow these accounts (number of followers) is 254 while the maximum number is $8,700,000$, with an average number of 532,399 . Finally, the minimum number of posted pictures on these accounts is 8 while the maximum number is 24,900 with an average number of 3830 .

\section{CONCLUSIONS}

\section{Research contributions}

Compare to previous knowledge on s-commerce research, this study has achieved five contributions. First, unlike the majority of studies that focused on socialization of OSN tools, this study is among the few initiatives (e.g. Hajli 2013; Akman and Mishra 2017) that focused on s-commerce acceptance and succeeded to explain the user acceptance of Instagram for e-commerce purposes. Second, following the suggestion of Akman and Mishra (2017), we used a qualitative approach for data collection with a large sample (we conducted 102 interviews with 102 real customers) and we considered more drivers of scommerce adoption than previous studies (Akman and Mishra 2017). Third, unlike Hajli (2013) who proposed only a theoretical research model, this study succeeded to identify 17 drivers of s-commerce adoption by customers in Kuwait beyond the use of OSN for socialization. Also this research managed in identifying, for the first time, two new constructs in technology (s-commerce) adoption represented here by the unique characteristics of Instagram and comparison of convenience. Fourth, this study succeeded to identify a list of measures/indicators for s-commerce adoption which will be useful for the second phase of this project to test a model for s-commerce adoption that is proper to Instagram in an Arab country. Fifth, we used a large sample of participants and a large number of interviews, which enabled us to provide deep understanding about s-commerce adoption issues. The 17 emerging factors were shown to impact the use of Instagram in s-commerce in Kuwait. This will contribute to influence marketing efforts toward attracting more customers to s-commerce in Kuwait and even elsewhere. These results do confirm and extend the understanding provided by previous empirical studies about s-commerce (Hsiao et al., 2010; Yoo et al. 2013; Akman and Mishra 2017). In addition, while Salvatori and Marcant (2015) called for the development of new models theories for s-commerce, the results of our qualitative study show clearly important determinants of s-commerce adoption, which could be included in a model and further investigated empirically. This is of importance to future studies looking to operationalize and implement the identified indicators/measure here in any future empirical studies about s-commerce adoption.

\section{Study limitations and future research perspectives}

While the study contributed in identifying 17 drivers for s-commerce adoption in Kuwait, still the study is limited with regards to the cause and effect between those drivers (exogenous variables) and endogenous variables (e.g., intention to use, current use, eWoM). Accordingly, we encourage future studies that will investigate the types of relationships between these identified constructs using appropriate scales/items based on the findings of this study, to collect large data from Kuwait and Arab countries, as well as to use structural equation modeling techniques (based on LISREL, Amos or PLS) in order to identify potential significant paths and create more generalizable results. 


\section{ACKNOWLEDGEMENTS}

This research was funded by Kuwait University, Research Grant IQ 02/16. The author acknowledges the Research Administration Project for its support.

\section{REFERENCES}

Agag, G., \& El-Masry, A. A. (2016). Understanding consumer intention to participate in online travel community and effects on consumer intention to purchase travel online and WoM: An integration of innovation diffusion theory and TAM with trust. Computers in Human Behavior, 60, 97-111.

Akman, I., \& Mishra, A. (2017). Factors influencing consumer intention in social commerce adoption. Information Technology \& People, 30(2), doi: 10.1108/ITP-01-2016-0006

Aladwani, A.M., \& Almarzouq, M. (2016). Understanding compulsive social media use: The premise of complementing self-conceptions mismatch with technology. Computers in Human Behavior 60, 575581 .

Al-Debei, M. M., Mohamed, M. N., \& Ashouri, N. (2015). Consumer attitudes towards online shopping. Internet Research, 25(5), $707-733$.

Al-Omoush, K., Yaseen, S., \& Alma'aitah, M. (2012). The impact of Arab cultural values on online social networking: The case of Facebook. Computers in Human Behavior, 28, 2387-2399.

Alwagait, E., Shahzad, B., Alim, S. (2015). Impact of social media usage on students academic performance in Saudi Arabia. Computers in Human Behavior, 51, 1092-1097.

Chaffey, D. (2016). Global social media research summary 2016. http://www.smartinsights.com/social-mediamarketing/social-media-strategy/new-global-social-media-research/ Accessed April 21th 2016

Chen, X. \& Tao, J. (2012). The Impact of Users' Participation on EWoM on Social Commerce Sites: An Empirical Analysis Based on Meilishuo.com. Fourth International Conference on Multimedia Information Networking and Security, 810-815.

Chen, Y., Yan, X., Fan, W., Gordon, M. (2015). The joint moderating role of trust propensity and gender on consumers' online shopping behavior. Computers in Human Behavior, 43, 272-283.

Dennison, G., Bourdage-Braun, S., \& Chetuparambil, M. (2009). Social commerce defined. White paper no. 23747, IBM, Research Triangle Park, NC, November 2009.

Gallivan, M. (1997). Value in Triangulation: A comparison of two approaches for combining qualitative and quantitative methods. In Lee, A., Liebenau, J., \& DeGross, J. (Eds.). Information systems and qualitative research (pp. 417-443). London: Chapman \& Hall.

Greenlight (2016). Digital marketing Agency. Web: www.greenlightdigital.com

Hajli, H., (2013). A research framework for social commerce adoption. Information Management \& Computer Security, 21(3),144-154, doi: 10.1108/IMCS-04-2012-0024

Hajli, N., Shanmugam, M., Powell, P., \& Love, P. E. (2015). A study on the continuance participation in on-line communities with social commerce perspective. Technological Forecasting and Social Change, 96, 232-241.

Hennig-Thurau, T., Gwinner, K. P., Walsh, G., \& Gremler, D. D. (2004). Electronic word-of-mouth via consumer-opinion platforms: What motivates consumers to articulate themselves on the Internet? Journal of Interactive Marketing, 18(1), 38-52. 
Hong, W., Chan F. K. Y., Thong, J. Y. L., Chasalow, L. C., \& Dhillon, G. (2014). A Framework and Guidelines for Context-Specific Theorizing in Information Systems Research. Information Systems Research 25(1), 111-136.

Hsiao, K., Lin, J.C., Wang, X., Lu, H., \& Yu, H. (2010). Antecedents and consequences of trust in online product recommendations: An empirical study in social shopping. Online Information Review, 34(6), 935-953, doi: 10.1108/14684521011099414

Hu, T., Kettinger, W. J., \& Poston, R. S. (2015). The effect of online social value on satisfaction and continued use of social media. European Journal of Information Systems, 24, 391-410.

Huang, Z., \& Benyoucef, M. (2013). From e-commerce to social commerce: A close look at design features. Electronic Commerce Research and Applications, 12(4), 246-259, Social Commerce- Part 2.

Kuwaitiful (2017). Kuwait is the most popular country on Instagram, http://248am.com/mark/interesting/kuwait-is-the-most-popular-country-on-instagram/ Accessed $07 / 05 / 2017$

Kuwaittimes.net (2016). Social media in Kuwait: a double-edged sword - 72\% Kuwaitis use Social media 5+ hours a day - Kuwait Times, published 29.07.2016; web : http://news.kuwaittimes.net/website/socialmedia-kuwait-double-edged-sword-72-kuwaitis-use-social-media-5-hours-day/

Lee, J. Y. (2016). Trust and Social Commerce, web: http://www.lexisnexis.com.kulibrary.vdiscovery.org/hottopics/lnacademic/?shr=t\&csi=7352\&sr=TITL $\mathrm{E}(\% 22$ Trust + social + commerce $\% 22)+$ and + date + is +2015

Liang, T., \& Turban, E. (2011). Introduction to the Special Issue Social Commerce: A Research Framework for Social Commerce. International Journal of Electronic Commerce, 1-13.

Limayem, M., Hirt, S. G., \& Cheung, C. M. K. (2007). How Habit Limits the Predictive Power of Intentions: The Case of IS Continuance. MIS Quarterly, 31(4), 705-737.

Lu, B., Fan, W., \& Zhou, M. (2016). Social presence, trust, and social commerce purchase intention: An empirical research. Computers in Human Behavior, 56, 225-237.

Magalhaes, R., \& Musallam, B. (2014). Investigating Electronic Word-of-Mouth Motivations in the Middle East: Twitter as Medium and Message. Journal of Electronic Commerce in Organizations, 12(3), 4059.

Oliver, R. L. (1981). Measurement and evaluation of satisfaction processes in retail settings. Journal of Retailing, 57(3) 25-48.

Oliver, R. L., \& DeSarbo, W. S. (1988). Response determinants in satisfaction judgments. Journal of Consumer Research, 14, 495-508.

Orlikowski, W. \& Baroudi, J. (1991). Studying information technology in organisations: Research approaches and assumptions. Information Systems Research, 2(1), 1-28.

Poon, S. \& Swatman, P. (1999b). A longitudinal study of expectations in small business Internet commerce. International Journal of Electronic Commerce, 3(3), 21-33.

Rouibah, K. (2016). Factors in the Choice of MIS as a Major: The Role of Subjective Norms from the Perspective of an Arab Country. Journal of Global Information Management, 24(03), 21-45.

Rouibah, K. (2016). Factors in the Choice of MIS as a Major: The Role of Subjective Norms from the Perspective of an Arab Country. Journal of Global Information Management, 24(03), 21-45. 
Rouibah, K. \& Hasan, A. (2006). Modified Technology Acceptance Model for Camera Mobile Phone Adoption: Development and validation. Proceedings of the $17^{\text {th }}$ Australasian Conference on Information System, (pp.1-11), Adelaide $6^{\text {th }}-8^{\text {th }}$ December 2006, Australia; available on http://aisel.aisnet.org/acis2006/13

Rouibah, K. (2008). Social Usage of Instant Messaging by individuals outside the workplace in Kuwait: A structural Equation Model. IT \& People, 21(1), 34-68.

Rouibah, K., \& Hamdy, H. I., \& Al-Enezi, M. Z. (2009). Effect of management support, training, and user involvement on system usage and satisfaction in Kuwait. Industrial Management \& Data System 103(9), 338-356.

Rouibah, K., \& Lowry, P. B., \& Al-Mutairi, L. (2015). B2C Systems Success Dimensions: Testing a Modified DeLone \& McLean IS Success Model in Kuwait in an E-Commerce Context. Journal of Global Information Management, 23(3), 41-70.

Rouibah, K., Hasan, A., \& Rouibah, S. (2011). Factors affecting Camera Mobile Phone adoption before EShopping in the Arab world. Journal Technology in Society, 33, 271-283.

Rouibah, K., Lowry, P., \& Hwang, Y. (2016). The effects of perceived enjoyment and perceived risks on trust formation and intentions to use online payment systems: New perspectives from an Arab country. Electronic Commerce Research and Application, 19, 33-43.

Salvatori, L., \& Marcant, F. (2015). Social commerce: A literature review. Science and Information Conference 2015, July 28-30, 2015, London, UK.

Schaupp, L. C., Carter, L., \& McBride, M. E. (2010). E-file adoption: A study of U.S. taxpayers' intentions. Computers in Human Behavior, 26(4), 636-644.

Statista (2016). Usage penetration of Instagram in selected global regions as of 2 nd quarter 2014. Web http://www.statista.com/statistics/325567/instagram-penetration-regions, Accessed 26/06/2016.

Stephen, A. T., \& Toubia, O. (2010). Deriving Value from Social Commerce Networks. Journal of Marketing Research, 47(2), 215-228.; doi: http://dx.doi.org/10.1509/jmkr.47.2.215

Tarhini, A., El-Masri, M., Ali, M., Serrano, A. (2016). Extending the UTAUT model to understand the customers' acceptance and use of internet banking in Lebanon: A structural equation modeling approach. Information Technology \& People, 29(4), 830-849, doi: 10.1108/ITP-02-2014-0034

Theatlantic.com (2013). In Kuwait, Instagram Accounts Are Big Business; https:/www.theatlantic.com/technology/archive/2013/07/kuwait-instagram-accounts-are-bigbusiness/313382/

TNS (2015). Arab Social Media Report, Arab Social Media Influencer summit 2015, 17-18 Mars 2015, Dubai, web: http://www.arabsmis.ae/en/about/

Venkatesh, V., Thong, J. Y., \& Xu, X. (2012). Consumer acceptance and use of information technology: Extending the unified theory of acceptance and use of technology. MIS Quarterly, 36(1), 157-178.

Vishwanath, A. (2015), Diffusion of deception in social media: Social contagion effects and its antecedents. Information Systems Frontiers, 17(6), 1353-1367.

Weitzl, W. (2016). Measuring Electronic Word-of-Mouth Effectiveness: Developing and Applying the eWOM Trust Scale. Springer Gabler

Yoo, C. W., Sanders, G. L., \& Moon, J. (2013). Exploring the effect of e-WOM participation on e-Loyalty in ecommerce. Decision Support System, 55(3), 669-678.

Zhou, L., \& Zhang, P., Zimmermann, H. (2013). Social commerce research: An integrated view. Electronic Commerce Research and Applications, 12, 61-68. 